\title{
Factors related to the outcome of ICU patients with celebral hemorrhage
}

\author{
M Georgiadou*, P Trantzas, G Barbarousi, H Pavlou, M Eforakopoulou \\ From ESICM LIVES 2015 \\ Berlin, Germany. 3-7 October 2015
}

\section{Introduction}

Intracerebral hemorrhage is a severe condition frequently requiring intensive care admission and mechanical ventilation. Several studies have shown that morbidity and mortality are increased in ICU patients with cerebral hemorrhage.

\section{Objectives}

To investigate the factors associated to the outcome of ICU patients with cerebral hemorrhage.

\section{Methods}

We retrospectively studied 34 patients with cerebral hemorrhage ( 23 men, 11 women, mean age $64 \pm 15$ years) hospitalized in ICU of the KAT hospital in Athens. Demographic data of patients, the type, severity and treatment of cerebral hemorrhage, the predisposing factors, the comorbidities, the complications during ICU hospitalization and the outcome were recorded. T-student and chisquare tests were used for statistical analysis.

\section{Results}

Of the studied patients 16 (47\%) were improved and left the ICU and 18 (53\%) were died. The age, the type of hemorrhage (traumatic, spontaneous, subarachnoid, subdural, intracerebral hematoma) and the type of therapy (surgery or conservative) were not associated with outcome. The Glasgow Coma Scale (GCS) was greater $(\mathrm{p}<0.05)$, whereas the Charlson Comorbidity Index and the SAPS II score were lower in survived patients ( $\mathrm{p}=0.01$ and $p=0.003$ respectively). The prior use of anticoagulants as well as prolonged INR and APTT were correlated with mortality ( $\mathrm{p}<0.05, \mathrm{p}=0.01, \mathrm{p}<0.05$ respectively). Also, the recurrence of hemorrhage, liver dysfunction, hyperamylasemia and arrhythmia occurred during ICU

KAT General Hospital, ICU, Athens, Greece hospitalization were associated with poor outcome ( $\mathrm{p}=0.002, \mathrm{p}=0.01, \mathrm{p}<0.05$ respectively).

\section{Conclusions}

ICU patients with cerebral hemorrhage have poor outcome. The coexisting diseases, the previous use of anticoagulants and the complications during ICU hospitalization are associated with mortality.

Published: 1 October 2015

\section{References}

1. Moussa Riachy, et al: Prediction of the survival and functional ability of severe stroke patients after ICU therapeutic intervention. BMC Neurology $82008,24$.

2. Fanshawe $M$, et al: Outcome of stroke patients admitted to intensive care: experience from an Australian teaching hospital. Anaesth Intensive Care 2002, 30(5):628-32, Oct.

doi:10.1186/2197-425X-3-S1-A785

Cite this article as: Georgiadou et al.: Factors related to the outcome of ICU patients with celebral hemorrhage. Intensive Care Medicine Experimental 2015 3(Suppl 1):A785.

\section{SpringerOpen ${ }^{\circ}$}

( 2015 Georgiadou et al.; This is an Open Access article distributed under the terms of the Creative Commons Attribution License (http://creativecommons.org/licenses/by/4.0), which permits unrestricted use, distribution, and reproduction in any medium, provided the original work is properly cited.
Submit your manuscript to a SpringerOpen ${ }^{\circ}$ journal and benefit from:

- Convenient online submission

- Rigorous peer review

- Immediate publication on acceptance

- Open access: articles freely available online

- High visibility within the field

Retaining the copyright to your article

Submit your next manuscript at $>$ springeropen.com 